\title{
Detection of Glyphosate-Resistant Palmer Amaranth (Amaranthus palmeri) In Agricultural AReas of Mato Grosso, BRAZIL ${ }^{1}$
}

\author{
Deteç̧ão de Caruru-Palmeri (Amaranthus palmeri) Resistente ao Herbicida Glyphosate em \\ Áreas Agrícolas do Mato Grosso, Brasil
}

\author{
CARVALHO, S.J.P. ${ }^{2}$, GONÇALVES NETTO, A. ${ }^{3}$, NICOLAI, M. ${ }^{4}$, CAVENAGHI, A.L. ${ }^{5}$, \\ LÓPEZ-OVEJERO, R.F. ${ }^{6}$, and CHRISTOFFOLETI, P.J. ${ }^{3}$
}

\begin{abstract}
The recent introduction of Palmer amaranth (Amaranthus palmeri) in Brazilian agricultural areas may promote several changes on weed management, especially in no-till systems and in glyphosate-resistant crops, since glyphosate-resistant biotypes of A. palmeri have been frequently selected in other countries. Therefore, this research was developed in order to evaluate the glyphosate susceptibility of a Palmer amaranth biotype recently identified in the State of Mato Grosso, Brazil. For this purpose, glyphosate susceptibility of three Amaranthus biotypes was compared: A. hybridus var. patulus, collected in the State of Rio Grande do Sul - Brazil; A. hybridus var. patulus, collected in the State of São Paulo - Brazil; and A. palmeri, collected in the State of Mato Grosso - Brazil. Dose-response curves were generated for all biotypes, considering eight rates of glyphosate and six replicates. All the experiments were repeated twice. Both A. hybridus biotypes were satisfactorily controlled by glyphosate, demanding rates equal to or lower than $541.15 \mathrm{~g}$ a.e. ha ${ }^{-1}$ for $80 \%$ control $\left(\mathrm{LD}_{80}\right)$. The A. palmeri biotype was not controlled by glyphosate in any of the assessments and required rates greater than $4,500 \mathrm{~g}$ a.e. $\mathrm{ha}^{-1}$ to reach $\mathrm{LD}_{80}$, which are economically and environmentally unacceptable. Comparison of the Brazilian A. palmeri biotype to the A. hybridus biotypes, as well as, to the results available in scientific international literature, led to the conclusion that the Brazilian Palmer amaranth biotype is resistant to glyphosate.
\end{abstract}

Keywords: pigweeds, susceptibility, dose-response, management, control.

RESUMO - A recente introdução da espécie Amaranthus palmeri em áreas agrícolas brasileiras pode promover significativas alterações no manejo de plantas daninhas, sobretudo em áreas de plantio direto e de cultivo de culturas resistentes ao glyphosate, uma vez que biótipos de A. palmeri resistentes ao glyphosate têm sido sistematicamente selecionados em outros paises. Assim, este trabalho foi desenvolvido com o objetivo de avaliar a suscetibilidade ao herbicida glyphosate do biótipo de A. palmeri que foi recentemente identificado no Estado de Mato Grosso, Brasil. Para isso, procedeu-se à comparação da suscetibilidade ao glyphosate de três biótipos de caruru: A. hybridus var. patulus, coletado no Estado do Rio Grande do Sul - Brasil; A. hybridus var. patulus, coletado no Estado de São Paulo - Brasil; e A. palmeri, coletado no Estado de Mato Grosso - Brasil. Para todos os biótipos, foram desenvolvidos experimentos com curvas de doseresposta, considerando-se oito doses de glyphosate e seis repetições. Todos os experimentos foram realizados duas vezes. Ambos os biótipos de A. hybridus foram controlados satisfatoriamente pelo herbicida glyphosate, exigindo doses iguais ou inferiores a 541,15 g e.a. ha- para $80 \%$ de controle $\left(D L_{80}\right)$. O biótipo de A. palmeri não foi controlado com o herbicida glyphosate em nenhuma das avaliações, exigindo doses superiores a $4.500 \mathrm{~g}$ e.a. ha $\mathrm{h}^{-1}$ para alcançar $D L_{80}$, as quais são inviáveis econômica e ambientalmente. A comparação do biótipo brasileiro de A. palmeri com os biótipos de A. hybridus, bem como com os resultados disponiveis na literatura cientifica internacional, permite concluir que se trata de um biótipo de caruru-palmeri resistente ao herbicida glyphosate.

Palavras-chave: resistência, suscetibilidade, dose-resposta, manejo, controle.

Recebido para publicação em 28.8.2015 e aprovado em 31.8.2015.

IFSULDEMINAS, Machado-MG, Brasil, <sjpcarvalho@yahoo.com.br>; ${ }^{3}$ Esalq/USP, Piracicaba-SP, Brasil; ${ }^{4}$ AGROCON Assessoria Agronômica Ltda., Santa Bárbara d’Oeste-SP, Brasil; ${ }^{5}$ Centro Universitário de Várzea Grande, Várzea Grande-MT, Brasil; ${ }^{6}$ Monsanto do Brasil, São Paulo-SP, Brasil. 


\section{INTRODUCTION}

There are about 60 species of plants classified into Amaranthus genus, and approximately 10 of those are important weeds in Brazilian agricultural systems (Kissmann \& Groth, 1999; Senna, 2015). The Amaranthus genus is present in most agricultural areas of the country, and among the most common species are A. deflexus, A. hybridus, A. lividus, $A$. retroflexus, $A$. spinosus, and $A$. viridis, all of which classified as monoecious species (Kissmann \& Groth, 1999; Carvalho et al., 2006).

The main causes for herbicide control failure of Amaranthus spp. are long periods of germination/emergence from the soil seed bank; fast growth and development; high production of viable seeds; long dormancy of the seeds in the soil and speciation difficulty during the early growth stages, when control is most adopted (Horak \& Loughin, 2000; Carvalho, 2015). Plants of the Amaranthus genus have Kranz leaf anatomy (Ferreira et al., 2003), typical of species with C4 photosynthetic cycle, providing efficiency in the production of carbohydrates in wormer and drier environments, especially when compared to $\mathrm{C} 3$ crops, such as soybean and cotton (Carvalho, 2015). These features render Amaranthus a high competitive ability with crops for light, water, and nutrients (Guo \& Al-Khatib, 2003; Silva et al., 2010; Barroso et al., 2012). The negative interference intensity of Amaranth on crop growth, development, and yield is dependent on the crop species, density and time of emergence (Klingaman \& Oliver, 1994; Knezevic et al., 1997).

Amaranthus species control in Brazil was recently aggravated due to the detection of a new species in agricultural areas of Mato Grosso State, the Palmer amaranth (Amaranthus palmeri) (Andrade Júnior et al., 2015). Unlike Amaranthus species commonly found in Brazil, A. palmeri is a dioecious plant, native of North America, and has been currently recognized as one of the most troublesome weeds in agricultural areas of the United States, particularly for cotton (Neve et al., 2011; Sosnoskie et al., 2011; Andrade Júnior et al., 2015; Webster \& Grey, 2015). In noncompetitive conditions, one plant of A. palmeri may produce 446,000 seeds; in competition with cotton, seed production is $30 \%$ lower, i.e., 312,000 seeds, which is still considered an extremely high value (Webster \& Grey, 2015).

Compared to the other species of the Amaranthus genus, Palmer amaranth has a more aggressive growth habit and is therefore extremely competitive with crops, even at low population densities (Rowland et al., 1999; Massinga et al., 2001). When an A. palmeri population is not properly controlled, it might promote yield losses up to $91 \%$ in corn, $79 \%$ in soybean and $77 \%$ in cotton (Andrade Júnior et al., 2015). High competitiveness of this weed was also demonstrated by Morgan et al. (2001); when competing with A. palmeri, the cotton canopy volume was decreased by $45 \%$ 10 weeks after cotton emergence. At the highest infestation density, the reduction in cotton biomass was greater than 50\%, eight weeks after emergence. In turn, the yield of cotton was reduced linearly between 13 and $54 \%$ due to the increased density from 1 to 10 Palmer amaranth plants per $9.1 \mathrm{~m}$ of row.

Therefore, A. palmeri is a species of great agricultural importance. There are currently 49 reported cases of herbicide-resistant Palmer amaranth biotypes globally, with several mechanisms of resistance, including cases of multiple resistance (Heap, 2015). The hypothesis of the Brazilian biotype being resistant to glyphosate was approached by Andrade Junior et al. (2015), but this finding still needs scientific confirmation. Thus, this research was developed in order to evaluate glyphosate-susceptibility of a Palmer amaranth (Amaranthus palmeri) biotype recently identified in the State of Mato Grosso, Brazil.

\section{MATERIAL AND METHODS}

All research was developed in a greenhouse of the Federal Institute of Education, Science and Technology of the South of Minas Gerais, Machado Campus, Brazil (21 40' S, 45 55' W, 850 m) between November 2014 and May 2015. Six experiments were carried out in order to evaluate glyphosate-susceptibility of 
Amaranthus biotypes, all based on traditional protocols as discussed by Carvalho et al. (2009). Experiments were conducted with three biotypes of Amaranthus: A. hybridus var. patulus, collected in the State of Rio Grande do Sul (AMAHY - RS); A. hybridus var. patulus, collected in the State of São Paulo (AMAHY -SP); and A. palmeri, collected in the State of Mato Grosso (AMAPA - MT), the latter in the same site where the presence of the species was firstly reported by Andrade Júnior et al. (2015).

Initially, seeds of each biotype were distributed in 2,0 L volume trays filled with commercial substrate. After emergence, seedlings were transplanted into $1,0 \mathrm{~L}$ plastic pots filled with mixture of commercial substrate, sieved clay soil, and vermiculite in a 6:3:1 ratio, respectively, at eight plants per pot. Pots were properly fertilized with macro and micronutrients. Additionally, 30 days after transplanting, calcium nitrate $(0.5 \mathrm{~g}$ per pot) and magnesium sulfate $(0.25 \mathrm{~g}$ per pot) were added. The pots were kept under automated irrigation system, avoiding water deficit to plants.

For evaluating glyphosate-susceptibility, independent experiments were considered for each biotype in a randomized block design with eight herbicide rates and six replications. For A. hybridus biotypes, glyphosate was sprayed in the following rates (g a.e. ha ${ }^{-1}$ ): 2,$880 ; 1,440 ; 720 ; 360 ; 180 ; 90$; and 45 . For A. palmeri, spray rates were (g a.e. $\left.\mathrm{ha}^{-1}\right)$ : 23,080; 11,520; 2,880; 1,440; 720; 360; and 90. All the experiments contained check plots (no herbicide application) as negative control and were repeated twice.

Plants were sprayed in the six true leaves growth stage. For this purpose, an experimental $\mathrm{CO}_{2}$ - pressurized, backpack sprayer coupled to one nozzle (flat fan - TeeJet XR 110.02) was adopted. The sprayer was positioned $0.50 \mathrm{~m}$ above the target surface and adjusted to a consumption rate of spray solution proportional to $200 \mathrm{~L} \mathrm{ha}^{-1}$. After herbicide application, pots were placed in the greenhouse and irrigated on the following day to secure perfect foliar absorption of the molecules.

Amaranth percentage control was evaluated at 14,21 , and 28 days after application (DAA), as was the residual dry mass at 28 DAA. For control evaluations, a $0-100 \%$ percentage scale was considered, where 0 represents the absence of symptoms and 100 plant death. Plant dry masses were obtained from harvesting all remaining plant material in the plots, with subsequent drying in an oven at $70{ }^{\circ} \mathrm{C}$ for 72 hours. Dry mass values were corrected to percentage by comparing the residual mass of each plot submitted to the different herbicide rates to the mass of the check plots (herbicide absence), considered as $100 \%$.

All data was submitted to the $\mathrm{F}$ test on variance analysis. For the same biotype, repeated experiments were analyzed according to the methodology of group of experiments. Then, quantitative information (doseresponse curves) was fitted to non-linear log-logistic models as proposed by Streibig (1988) (percent control (eq. 1)) and Seefeldt et al. (1995) (residual dry mass (eq. 2)):

$$
\begin{aligned}
& y=\frac{a}{\left[1+\left(\frac{x}{b}\right)^{c}\right]} \\
& y=P \min +\frac{a}{\left[1+\left(\frac{x}{b}\right)^{c}\right]}
\end{aligned}
$$

where: $y$ is the variable (control or percentage dry mass), $x$ is the herbicide rate (g a.e. ha ${ }^{-1}$ ), $P$ min is the minimum curve value, and $a, b$, and $c$ are parameters of the model; where $a$ is the amplitude between the maximum and the minimum variable value, $b$ is the herbicide rate that provides $50 \%$ of variable response, and $c$ is the slope of the curve around $b$.

The log-logistic model has advantages, once one of the equation parameters $(b)$ is an estimative of $\mathrm{LD}_{50}$ or $\mathrm{GR}_{50}$ (Christoffoleti, 2002). The $\mathrm{LD}_{50}$ (lethal dose to $50 \%$ of the population) or $\mathrm{GR}_{50}$ (growth reduction by $50 \%$ ) is the herbicide rate (g a.e. ha $^{-1}$ ) which provides $50 \%$ of percentage control or weed dry matter reduction, respectively (Christoffoleti, 2002; Carvalho et al., 2009). Although one parameter 
of the logistic model $(b)$ is a $\mathrm{LD}_{50}$ or $\mathrm{GR}_{50}$ estimate, it also underwent mathematical calculation as did $\mathrm{LD}_{80}$ and $\mathrm{GR}_{80}$ estimates through the inverse equation based on the discussion proposed by Carvalho et al. (2005).

\section{RESULTS E DISCUSSION}

The identification of an Amaranthus palmeri biotype in the State of Mato Grosso was the first national report of the presence of this weed species in Brazil (Andrade Júnior et al., 2015), greatly restricting the possibility to collect seeds from other $A$. palmeri populations which could be used for comparing glyphosatesusceptibility among biotypes. Therefore, to validate the discussions on the results of this work, $\mathrm{GR}_{50}$ and $\mathrm{LD}_{50}$ values from characterized glyphosate-susceptible biotypes of A. palmeri (Table 1) were obtained from the literature, which indicated $\mathrm{LD}_{50}$ and $\mathrm{GR}_{50}$ values between 30 and 150 g a.e. ha ${ }^{-1}$, with overall averaged of $105.2 \mathrm{~g}$ a.e. ha ${ }^{-1}$.

The log-logistic models provided appropriate adjustment of data set, with significant model fit ( $F$ test) and coefficients of determination always higher than 97\% (Table 2). Compared to the rates regularly used to control several species of amaranth in field conditions, both A. hybridus biotypes were perfectly controlled by glyphosate applications, with similar values of $\mathrm{LD}_{50}$ and $\mathrm{GR}_{50}$. For $A$. hybridus, the highest value of $\mathrm{DL}_{80}$ was $541.15 \mathrm{~g}$ a.e. ha ${ }^{-1}$, which was reached for the biotype collected in Rio Grande do Sul at the evaluation held at 14 DAA. Therefore, both biotypes of $A$. hybridus can be considered susceptible to glyphosate since the usual recommended dose is $720 \mathrm{~g}$ a.e. ha ${ }^{-1}$ (Rodrigues \& Almeida, 2011).

Conversely, the $A$. palmeri biotype was not controlled with commercial rates of glyphosate in any of the evaluations or variables (Table 2). At 14 DAA, 1,771.59 g a.e. ha ${ }^{-1}$ of glyphosate rate was necessary to obtain $50 \%$ of control. Therefore, there is a significant difference between the control patterns obtained for the A. hybridus and A. palmeri biotypes at 14 and 21 DAA (Figure 1). A significant difference in control pattern also holds for the evaluations carried out at 28 DAA (Figure 2). In this assessment, a glyphosate rate of $14,294.36 \mathrm{~g}$ a.e. ha ${ }^{-1}$ was required for $80 \%$ dry weight reduction in plants (Table 2), which is considered economically and environmentally unfeasible.

The world's first case of a glyphosateresistant Palmer amaranth biotype was documented by Culpepper et al. (2006), who studied a biotype collected in the state of Georgia (USA). In that work, authors found $L_{50}$ values of $150 \mathrm{~g}$ a.e. ha ${ }^{-1}$ for the susceptible biotype of Palmer amaranth (Table 1) and greater than 1,200 g a.e. ha-1 for the resistant biotype. To obtain full control of the glyphosate-resistant $A$. palmeri biotype, Culpepper et al. (2006) reported a required glyphosate rate of 7,200 g a.e. ha ${ }^{-1}$, which is much lower than that required for the Brazilian biotype $\mathrm{DL}_{80}$.

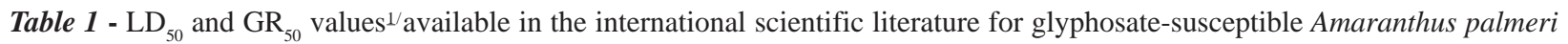
biotypes, estimated by dose-response curves

\begin{tabular}{|c|c|c|c|c|}
\hline Author & Site & $\begin{array}{c}\text { Stage of } \\
\text { application } \\
\text { (height/leaves) }\end{array}$ & $\begin{array}{l}\text { Evaluation } \\
\text { timing }\end{array}$ & Results $^{\underline{1}}$ \\
\hline Culpepper et al., 2006 & Georgia - USA & $7-10 \mathrm{~cm}$ & $20 \mathrm{DAA}^{2 /}$ & $\begin{aligned} \mathrm{LD}_{50} & =150 \mathrm{~g} \mathrm{ha}^{-1} \\
\mathrm{GR}_{50} & =90 \mathrm{~g} \mathrm{ha}^{-1}\end{aligned}$ \\
\hline Norsworthy et al., 2008a $a^{3 /}$ & Arkansas - USA & 5 - 7 leaves & 28 DAA & $\mathrm{LD}_{50}=30 \mathrm{~g} \mathrm{ha}^{-1}$ \\
\hline Norsworthy et al., 2008b $\mathrm{b}^{3 /}$ & Arkansas - USA & 5 - 7 leaves & 28 DAA & $\mathrm{LD}_{50}=114 \mathrm{~g} \mathrm{ha}^{-1}$ \\
\hline Sosnoskie et al., 2011 & Georgia - USA & $10-15 \mathrm{~cm}$ & 3 - 4 weeks & $\mathrm{LD}_{50}=91 \mathrm{~g} \mathrm{ha}^{-1}$ \\
\hline Nandula et al., 2012 & Mississippi - USA & 4 - 6 leaves & 3 weeds & $\mathrm{GR}_{50}=90 \mathrm{~g} \mathrm{ha}^{-1}$ \\
\hline Mohseni-Moghadam et al., 2013 & New Mexico - USA & 3 - 4 leaves & 16 DAA & $\mathrm{GR}_{50}=66 \mathrm{~g} \mathrm{ha}^{-1}$ \\
\hline \multicolumn{4}{|c|}{ General average values ${ }^{\underline{3}}$} & $105.2 \mathrm{~g} \mathrm{ha}^{-1}$ \\
\hline
\end{tabular}

${ }_{1 /}^{\prime}$ Results expressed in grams of glyphosate (acid equivalent) required for $50 \%$ of population control $\left(\mathrm{LD}_{50}\right)$ or for $50 \%$ of growth reduction $\left(\mathrm{GR}_{50}\right)$; 늘 DAA - days after application; $\underline{3}$ / average value of susceptible biotypes. 
Table 2 - Variables, parameters of log-logistic model, F test, coefficient of determination $\left(\mathrm{R}^{2}\right)$, lethal dose (LD) or growth reduction (GR) for glyphosate susceptibility of three Amaranth biotypes. Machado - MG, 2015

\begin{tabular}{|c|c|c|c|c|c|c|c|c|c|}
\hline \multirow{2}{*}{\multicolumn{2}{|c|}{ Variable }} & \multicolumn{4}{|c|}{ Parameter } & \multirow{2}{*}{$\mathrm{F}$} & \multirow{2}{*}{$\mathrm{R}^{2}$} & \multicolumn{2}{|c|}{ LD or GR } \\
\hline & & $\mathrm{P}_{\min }$ & $\mathrm{a}$ & $\mathrm{b}$ & C & & & 50 & 80 \\
\hline \multicolumn{10}{|c|}{ Amaranthus hybridus - Biotype collected in the State of Rio Grande do Sul - Brazil } \\
\hline \multirow{3}{*}{ Control } & $14 \mathrm{DAA}^{2} /$ & -- & 102.332 & 242.422 & -1.589 & $747.31 *$ & 0.997 & 235.57 & 541.15 \\
\hline & 21 DAA & -- & 99.954 & 238.843 & -1.948 & $219.69 *$ & 0.989 & 238.96 & 487.18 \\
\hline & 28 DAA & -- & 99.632 & 251.886 & -1.997 & $232.12 *$ & 0.989 & 252.82 & 509.01 \\
\hline \multicolumn{2}{|c|}{ Dry weight (\%) } & 4.540 & 97.395 & 137.137 & 1.976 & $271.14^{*}$ & 0.995 & 146.70 & 318.92 \\
\hline \multicolumn{10}{|c|}{ Amaranthus hybridus - Biotype collected in the State of São Paulo - Brazil } \\
\hline \multirow{3}{*}{ Control } & $14 \mathrm{DAA}$ & -- & 101.505 & 207.534 & -1.826 & $2754.60 *$ & 0.999 & 204.19 & 426.14 \\
\hline & $21 \mathrm{DAA}$ & -- & 101.700 & 189.621 & -1.980 & 1029.20* & 0.997 & 186.45 & 366.49 \\
\hline & $28 \mathrm{DAA}$ & -- & 101.138 & 170.545 & -1.701 & 2284.46* & 0.998 & 168.30 & 372.95 \\
\hline \multicolumn{2}{|c|}{ Dry weight (\%) } & 4.349 & 97.595 & 142.011 & 2.481 & $760.59 *$ & 0.998 & 149.60 & 276.77 \\
\hline \multicolumn{10}{|c|}{ Amaranthus palmeri - Biotype collected in the State of Mato Grosso - Brazil } \\
\hline \multirow{3}{*}{ Control } & 14 DAA & -- & 104.310 & 1900.068 & -1.181 & $682.16^{*}$ & 0.993 & 1771.59 & 5209.45 \\
\hline & $21 \mathrm{DAA}$ & -- & 104.259 & 1773.982 & -1.189 & $233.82 *$ & 0.979 & 1656.12 & 4839.41 \\
\hline & 28 DAA & -- & 105.188 & 1599.662 & -1.107 & 238.58* & 0.979 & 1463.18 & 4543.73 \\
\hline \multicolumn{2}{|c|}{ Dry weight (\%) } & 16.529 & 86.797 & 977.986 & 1.185 & $144.11 *$ & 0.986 & 1448.85 & 14294.36 \\
\hline
\end{tabular}

$\underline{1} / \mathrm{y}=\mathrm{a} /\left(1+(\mathrm{x} / \mathrm{b})^{\mathrm{c}}\right)$ ou $\mathrm{y}=\mathrm{P}_{\min }+\mathrm{a} /\left(1+(\mathrm{x} / \mathrm{b})^{\mathrm{c}}\right)$; ${ }^{2} / \mathrm{DAA}$ - days after application; * significant at $1 \%$ probability level.

Similarly, studying a glyphosate-resistant biotype of $A$. palmeri collected in the state of Arkansas (USA), Norsworthy et al. (2008a) found $\mathrm{LD}_{50}$ values of $2,820 \mathrm{~g}$ a.e. ha-1. Additionally, a 12,500 g a.e. ha ${ }^{-1}$ glyphosate rate was necessary for a $\mathrm{DL}_{95}$ for the same biotype, which was considered 15 fold higher than the usual rate for the control of this species. Assessing another glyphosateresistant A. palmeri biotype collected in Georgia (USA), Sosnoskie et al. (2011) found $\mathrm{GR}_{50}$ and $\mathrm{LD}_{50}$ levels of 1,449.6 and 1,439.6 g a.e. ha ${ }^{-1}$, respectively. These results are very similar to those found for the biotype collected in the State of Mato Grosso (Table 2).

Thus, three relevant aspects must be highlighted: I. According to scientific studies conducted internationally, glyphosate rates required to control glyphosate-susceptible A. palmeri biotypes are usually lower than 150 g a.e. ha ${ }^{-1}$ (Table 1); II. The satisfactory control reached for $A$. hybridus biotypes validates the applications and the use of glyphosate for amaranth control; III. LD $_{50}$ and $\mathrm{GR}_{50}$ values found in the literature for glyphosate-resistant biotypes of $A$. palmeriare in agreement with those obtained in this study (Table 2). Therefore, it can be assumed with great degree of certainty that the biotype collected in the State of Mato Grosso, Brazil, is also resistant to glyphosate. This has an important practical application given the worsening of the problematic of amaranth species identification in Brazil and the fact that readjustments in amaranth species management will be strongly necessary, including the use of alternatives to glyphosatebased herbicide formulations, both for pre- and post-emergence application.

The next important step will be to evaluate the resistance mechanism of the Brazilian Palmer amaranth biotype. The majority of the reported cases of herbicide-resistant Amaranthus species is generally related to altered site of action, like the cases of resistance to photosystem II and ALS inhibiting herbicides (Dias et al., 2015). However, apparently this is not the case for glyphosate-resistant Palmer amaranth. A previously published work suggests the existence of different resistance mechanisms among A. palmeri biotypes (Ward et al., 2013). In laboratory experiments, Culpepper et al. (2006) found no differences in glyphosate absorption and translocation between resistant and susceptible biotypes, but shikimate accumulation was not detected in tissues of 

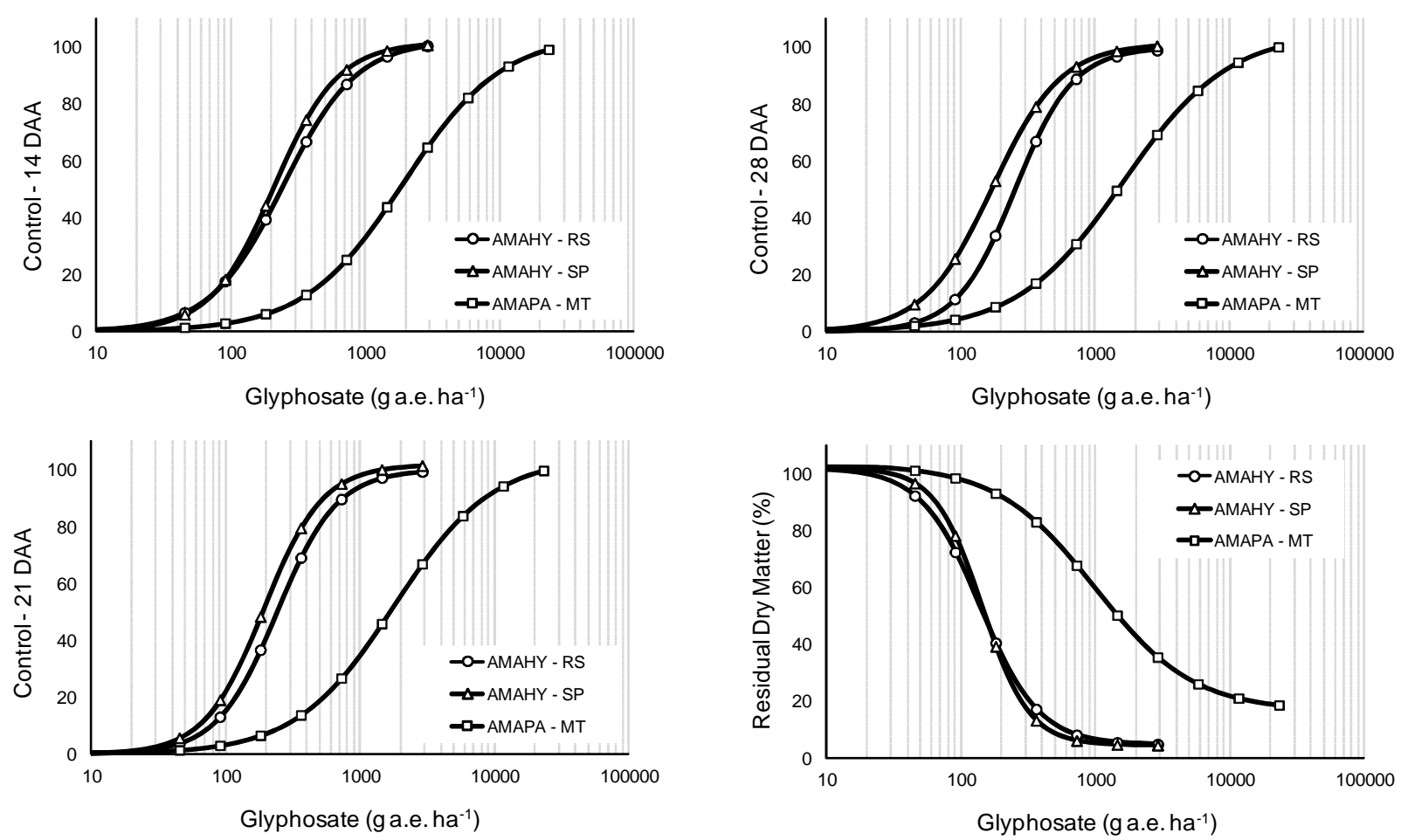

AMAHY-RS - A. hybridus var. patulus, collected in the State of Rio Grande do Sul, Brazil; AMAHY-SP - A. hybridus var. patulus, collected in the State of São Paulo, Brazil; AMAPA-MT A. palmeri, collected in the State of Mato Grosso, Brazil.

Figure 1 - Percentage control of Amaranthus biotypes submitted to different glyphosate application rates and evaluated at 14 and 21 days after application (DAA). Machado - MG, 2015.

the resistant Palmer amaranth biotype previously treated with glyphosate.

Recently, Nandula et al. (2012) found no differences in glyphosate metabolism between resistant and susceptible biotypes of $A$. palmeri when working with populations collected in the state of Mississippi (USA). However, those glyphosate-resistant biotypes absorbed less glyphosate 48 hours after treatment when compared to those that are susceptible. The authors also observed that the glyphosatesusceptible biotype accumulated more glyphosate in branches and leaves above the treated leaf, where the apical meristem is located. On the contrary, glyphosate-resistant biotypes accumulated glyphosate in the branches and leaves located below the treated leaves. The authors attributed the possible cause of resistance to reduced absorption and translocation of the glyphosate molecule.

AMAHY-RS - A. hybridus var. patulus, collected in the State of Rio Grande do Sul, Brazil; AMAHY-SP - A. hybridus var. patulus, collected in the State of São Paulo, Brazil; AMAPA-MT A. palmeri, collected in the State of Mato Grosso, Brazil.

Figure 2 - Percentage control and residual dry matter of Amaranthus biotypes submitted to different glyphosate application rates and evaluated at 28 days after application (DAA). Machado - MG, 2015.

From another standpoint, Gaines et al. (2010) investigated glyphosate-resistant biotypes of A. palmeri from Georgia (USA) and concluded that the activity of the enzyme EPSPs from resistant and susceptible plants was equally inhibited by glyphosate. However, genomes of resistant plants contained from 5 -fold to more than 160-fold additional copies of the EPSPs gene than did genomes of susceptible plants. Hence, authors proposed for the first time that EPSPs gene amplification is the molecular basis of the Georgia glyphosateresistant biotype. Mohseni-Moghadam et al. (2013) evaluated a A. palmeri biotype collected in the state of New Mexico (USA) and similarly concluded that resistance to glyphosate in the assessed biotype was due to increased EPSPs expression.

Collectively, the data presented herein leads to the conclusion that the Brazilian 
A. palmeri biotype recently introduced in the State of Mato Grosso is resistant to glyphosate when compared to both $A$. hybridus biotypes, also taking the international scientific literature standards into account. Therefore, Brazilian weed management practices should be reviewed considering the inclusion of alternative management methods, such as herbicides with different mode of action, use of pre-emergence herbicides and crop rotation, and the constant monitoring of infested areas. Additionally, some contention practices should be alerted to growers in order to avoid spreading of this amaranth species throughout the country.

\section{ACKNOWLEDGMENT}

The authors would like to thank the "Instituto Federal de Educação, Ciência e Tecnologia do Sul de Minas Gerais - IFSULDEMINAS", specially Machado Campus, for contributing to the development of this work.

\section{LITERATURE CITED}

ANDRADE JÚNIOR, E. R. et al. Primeiro relato de Amaranthus palmeri no Brasil em áreas agrícolas no estado de Mato Grosso. Cuiabá: 2015. 8 p.

(Circular Técnica IMA-MT, 19)

BARROSO, A. A. M. et al. Efeito da densidade e da distância de caruru-de-mancha e amendoim-bravo na cultura do feijoeiro. Planta Daninha, v. 30, n. 1, p. 47-53, 2012.

CARVALHO, S. J. P. et al. Curvas de dose-resposta para avaliação do controle de fluxos de emergência de plantas daninhas pelo herbicida imazapic. Planta Daninha, v. 23, n. 3, p. 535-542, 2005.

CARVALHO, S. J. P. et al. Suscetibilidade diferencial de plantas daninhas do gênero Amaranthus aos herbicidas trifloxysulfuron-sodium e chlorimuron-ethyl.

Planta Daninha, v. 24, n. 3, p. 541-548, 2006.

CARVALHO, S. J. P.; CHRISTOFFOLETI, P. J.; LÓPEZOVEJERO, R. F. Métodos para a comprovação da resistência de plantas daninhas a herbicidas. In: AGOSTINETTO, D.; VARGAS, L. Resistência de plantas daninhas a herbicidas no Brasil. Passo Fundo: Berthier, 2009. p. 103-122.

CARVALHO, S. J. P. Características biológicas de plantas daninhas do gênero Amaranthus. In.: INOUE, M. H. et al. Manejo de Amaranthus. São Carlos: RiMa, 2015. p. 21-36.
CHRISTOFFOLETI, P. J. Curvas de dose-resposta de biótipos resistente e suscetível de Bidens pilosa L. aos herbicidas inibidores da ALS. Sci. Agríc., v. 59, n. 3, p. 513-519, 2002.

CULPEPPER, A. S. et al. Glyphosate-resistant Palmer amaranth (Amaranthus palmeri) confirmed in Georgia. Weed Sci., v. 54, n. 4, p. 620-626, 2006.

DIAS, A. C. R.; MENDES, K. F.; INOUE, M. H. Resistência de espécies de plantas daninhas do gênero Amaranthus no mundo e no Brasil. In: INOUE, M. H. et al. Manejo de Amaranthus. São Carlos: RiMa, 2015. p. 105-118.

FERREIRA, E. A. et al. Estudos anatômicos de folhas de espécies de plantas daninhas de grande ocorrência no Brasil. IV - Amaranthus deflexus, Amaranthus spinosus, Alternanthera tenella e Euphorbia heterophylla. Planta Daninha, v. 21, n. 2, p. 263-271, 2003.

GAINES, T. A. et al. Gene amplification confers glyphosate resistance in Amaranthus palmeri. PNAS, v. 107, n. 3, p. 1029-1034, 2010.

GUO, P.; AL-KHATIB, K. Temperature effects on germination and growth of redroot pigweed (Amaranthus retroflexus), Palmer amaranth (A. palmeri), and common waterhemp (A. rudis). Weed Sci., v. 51, n. 6, p. 869-875, 2003.

HEAP, I. The international survey of herbicide resistant weeds. Disponível em: <http://www.weedscience.org>. Acesso em: 21 ago. 2015.

HORAK, M. J.; LOUGHIN, T. M. Growth analysis of four Amaranthus species. Weed Sci., v. 48, n. 3, p. 347-355, 2000.

KISSMANN, K. G.; GROTH, D. Plantas infestantes e nocivas. 2.ed. São Paulo: BASF, 1999. v. 2. 978 p.

KLINGAMAN, T. E.; OLIVER, L. R. Palmer amaranth (Amaranthus palmeri) interference in soybean (Glycine max). Weed Sci., v. 42, n. 4, p. 523-527, 1994.

KNEZEVIC, S. Z.; HORAK, M. J.; VANDERLIP, R. L. Relative time of redroot pigweed (Amaranthus retroflexus) emergence is critical in pigweed-sorghum [Sorghum bicolor (L.) Moench] competition. Weed Sci., v. 45, n. 4, p. 502-508, 1997.

MASSINGA, R. A. et al. Interference of Palmer amaranth in corn. Weed Sci., v. 49, n. 2, p. 202-208, 2001.

MOHSENI-MOGHADAM, M. et al. Resistance to glyphosate in Palmer amaranth (Amaranthus palmeri) populations from New Mexico pecan orchards. Weed Technol., v. 27, n. 1, p. 85-91, 2013. 
MORGAN, G. D.; BAUMANN, P. A.; CHANDLER, J. M. Competitive impact of Palmer amaranth (Amaranthus palmeri) on cotton (Gossypium hirsutum) development and yield. Weed Technol., v. 15, n. 3, p. 408-412, 2001.

NANDULA, V. K. et al. Multiple resistance to glyphosate and pyrithiobac in Palmer amaranth (Amaranthus palmeri) from Mississippi and response to flumiclorac. Weed Sci., v. 60, n. 2, p. 179-188, 2012.

NEVE, P. et al. Modeling glyphosate resistance management strategies for Palmer amaranth (Amaranthus palmeri) in cotton. Weed Technol., v. 25, n. 3, p. 335-343, 2011.

NORSWORTHY, J. K. et al. Confirmation and control of glyphosate-resistant Palmer amaranth (Amaranthus palmeri) in Arkansas. Weed Technol., v. 22, n. 1, p. 108-113, 2008a.

NORSWORTHY, J. K. et al. Response to northeastern Arkansas Palmer amaranth (Amaranthus palmeri) accessions to glyphosate. Weed Technol., v. 22, n. 3, p. 408-413, 2008b.

RODRIGUES, B. N.; ALMEIDA, F. S. Guia de herbicidas. Londrina: Edição dos Autores, 2011. 697 p.

ROWLAND, M. W. et al. Full-season Palmer amaranth (Amaranthus palmeri) interference with cotton (Gossypium hirsutum). Weed Sci., v. 47, n. 3, p. 305-309, 1999.
SEEFELDT, S. S.; JENSEN, J. E.; FUERST, E. P. Log-logistic analysis of herbicide dose-response relationship.

Weed Technol., v. 9, n. 2, p. 218-227, 1995.

SENNA, L. R. Identificação de espécies de plantas daninhas do gênero Amaranthus L. (Amaranthaceae Juss.) no Brasil. In: INOUE, M. H. et al. Manejo de Amaranthus. São Carlos: RiMa, 2015. p. 1-20.

SILVA, B. P. et al. Interferência de caruru-de-mancha, mariapretinha, picão-preto e tiririca em tomateiro industrial. Bragantia, v. 69, n. 2, p. 313-318, 2010.

SOSNOSKIE, L. M. et al. Multiple resistance in Palmer amaranth to glyphosate and pyrithiobac confirmed in Georgia. Weed Sci., v. 59, n. 3, p. 321-325, 2011.

STREIBIG, J. C. Herbicide bioassay. Weed Res., v. 28, n. 6, p. 479-484, 1988 .

WARD, S. M.; WEBSTER, T. M.; STECKEL, L. E. Palmer amaranth (Amaranthus palmeri): a review. Weed Technol., v. 27, n. 1, p. 12-27, 2013.

WEBSTER, T. M.; GREY, T. L. Glyphosate-resistant Palmer amaranth (Amaranthus palmeri) morphology, growth, and seed production in Georgia. Weed Sci., v. 63, n. 1, p. 264-272, 2015. 